\title{
EXPERIÊNCIAS DE INTERCÂMBIO
}

CANADÁ

PROMOÇÃO DA SAÚDE GLOBAL: CO-

RESPONSABILIDADE EM PESQUISA

Emília Luigia Saporiti Angerami*

O título deste relato é o da conferência por nós proferida na "International Nursing Research Conference - Making a difference. Meeting the Challenge" em maio 1994, Vancouver, Canadá, promoção científica em comemoração dos 75 anos da School of Nursing, University of British Columbia.

O encontro ofereceu a oportunidade de intercâmbio com reconhecidos pesquisadores e enfermeiros de diferentes países e de conhecer os avanços ocorridos na pesquisa em enfermagem. Os aspectos metodológicos foram enfatizados para delineamento de projetos de investigação e avaliação das intervenções de enfermagem.

Um tema tão abrangente como o da promoção da saúde global com enfoque na coresponsabilidade em pesquisa foi por nós desenvolvido num paradigma de saúde onde a pessoa e sujeito em atitude e reciprocidade. Abordamos o tema em três aspectos: - no primeiro apresentamos o conceito de co-responsabilidade e suas relações com a pesquisa e o pesquisador. No segundo analisamos as transformações no conceito de saúde e fizemos um relato de uma experiência realizada em uma pequena comunidade, a qual permitiu compreender o estado atual do sistema de saúde no Brasil. O terceiro introduz o conceito de direito e dever, permitindo, numa perspectiva holística, entendê-los e percebê-los em suas estruturas sócio-econômicas e culturais. Concluímos dizendo que o compromisso do cientista com a comunidade é uma atitude

* Professor Titular, Escola de Enfermagem de Ribeirão Preto. Universidade de São Paulo - Brasil 
desejável mais do que propriamente uma conquista, uma vez que, os modelos de formação de pesquisadores têm sido direcionados ao aprofundamento do conhecimento, relegando muitas vezes a sensibilidade.

Consideramos um desafio aceitar o convite feito a uma enfermeira Latino-Americana para apresentar um tema tão relevante num congresso mundial, no entanto ficou evidente que temos um corpo de conhecimento construído o qual merece ser divulgado, contribuindo assim para o desenvolvimento da enfermagem a nível internacional.

O assunto de projetos internacionais de investigação, nos mais diversos campos, é uma realidade e representa um enorme potencial, tanto para os países promotores como receptores e ao serem executados de forma apropriada, os resultados podem trazer benefícios incalculáveis.

Nesta perspectiva conhecemos diversos serviços de saúde e participamos de um encontro, na sede da "Registered Nurses Association of British Columbia, Vancouver", o qual teve como objetivo estudar as possibilidades de um projeto em parceria Brasil-Canadá.

Mesmo reconhecendo a polêmica criada para este tipo de atividade, qual seja profissionais estrangeiros com visão particular de mundo, o qual nem sempre é representativa de outro povo, pensamos ser possível familiarizar estes pesquisadores com as diferenças culturais, e estas serem consideradas nos estudos. Vale a pena acrescentar que a colaboração na investigação é um caminho para encurtar as distâncias entre países desenvolvidos e em desenvolvimento.

Quanto mais estreita for esta cooperação, quanto mais eficaz a comunicação entre os pesquisadores, mais respeito haverá aos países, ao cidadão, suas leis e autoridades.

Permanece o desafio de contarmos o mais breve possível com pesquisadores capazes de assumir e liderar projetos que permitam levar para a prática em saúde uma proposta concreta de co-responsabilidade. 